\title{
Estimation of Chlorophyll-a Phytoplankton in the Coastal Waters of Semarang and Jepara for Monitoring the Eutrophication Process using MODIS-Aqua Imagery and Conventional Methods
}

\author{
Lilik Maslukah¹, Riza Yuliratno Setiawan², Nurjannah Nurdin³, Muhammad Zainuri , \\ Anindya Wirastriya ${ }^{1}$, Muhammad Helmi ${ }^{1}$ \\ 1 Department of Oceanography, Faculty of Fisheries and Marine Science, Diponegoro University, Indonesia \\ 2 Department of Fisheries, Faculty of Agriculture, Gadjah Mada University, Yogyakarta, Indonesia \\ 3 Research and Development Center for Marine, Coast and Small Island, Hasanuddin University \\ * Correspondent author's e-mail: lilik_masluka@yahoo.com
}

\begin{abstract}
This study investigates the concentration of chlorophyll-a (chl-a) using the data of field observation and MODISAqua imagery. The field observation data were retrieved by using a conventional method and processed using spectrometric analysis. This study covers the coastal and near land areas which have different levels of anthropogenic activity. The results showed that the coastal waters of Semarang with a high level of anthropogenic activity persistently show a concentration of chlorophyll a (chl-a) twice as large as Jepara coastal waters. This comparison value is obtained based on imagery and field data. Meanwhile, the ratio of chl-a field data in each region shows a value of \pm 5 times greater than the MODIS data. Field observation data shows a higher value than the MODISAqua imagery data. The use of imagery data can be employed as a method of monitoring the eutrophication process on the coast. On the basis of the chlorophyll a classification and field observations, the coastal water of Semarang are classified as eutropic waters and Jepara is categorized as mesotropic category. The classification results will be different if monitoring is carried out using the image data with a location far from the mainland, the Semarang waters are included in the mesotropic category $\left(>2 \mathrm{mg} \cdot \mathrm{m}^{-3}\right)$ and Jepara is included in the oligotropic water category $\left(<2 \mathrm{mg} \cdot \mathrm{m}^{-3}\right)$.
\end{abstract}

Keywords: chlorophyll a, eutrophic, spectrometry, satellite, MODIS-Aqua

\section{INTRODUCTION}

The coastal waters represent only a small fraction of sea water on the planet, but the role they play is of great importance from an ecological, social, and economic perspective, by supplying about $90 \%$ of global fish yield and accounting for about $25 \%$ of global marine (Colella et al., 2016). At present, the coastal zone is one of the most endangered areas. Pollution, eutrophication, urbanisation, over-fishing, and tourism continually threaten the future of marine coastal ecosystems. The coastal waters are very sensitive to changes in nutrients input from the anthropogenic activities on land or in the marine coast itself, which can cause eutrophication. The terrestrial input has caused an increase in the rate of supply of organic matter to the ecosystem. One indicator of the eutrophication process is the increase in phytoplankton biomass. In coastal waters, the phytoplankton biomass can be used as an important water quality parameter (Poddar et al., 2019) because it is related to algal abundance, and can be used to determine the level of eutrophication in certain water bodies (Zheng \& DiGiacomo, 2017).

The state of the phytoplankton biomass is typically quantified with a proxy, e.g., by measuring the concentration of chlorophyll-a (chl-a), which is a ubiquitous photosynthetic pigment present in all algal species. The measurements of (chl-a) can be made in situ (e.g., chlorophyll fluorometers), remotely (with optical radiometers) (Brewin et 
al., 2019), as well as in the laboratory through the water sample analyses (Dickey et al., 2006). The conventional method of (chl-a) estimation requires water sample collection and laboratory analysis (Joint et al., 2000). This method, effortintensive and time consuming, is unsuitable for large spatio-temporal scales. The temporal and spatial sampling strategies of chlorophyll a concentrations important to monitor eutrophication. Instead, the satellite-based sensors can be used for the assessment of (chl-a) at large spatial scales. Currently, one operational ocean color sensor, Moderate Resolution Imaging Spectroradiometer (MODIS-Aqua), collects data with 1-2 days of temporal resolution.

The waters of the coast of Semarang and Jepara are part of the Java Sea and geographically the two coasts are in different parts. The Semarang waters are on the north side of Java Island, while Jepara is partly located on the west coast (west of Java Island). Semarang, which is located in the urban center of the capital, certainly has higher anthropogenic activity than Jepara. In addition, these waters are watersheds and bring material from the mainland to enter the waters (BPDAS Pemali Jeratun, 2009). Unlike the case of the Jepara waters which are affected by several rivers, such as Wiso river and Sapok river with smaller water discharge. The presence of the AustralianAsian monsoon will affect the season and current patterns in both waters and affect the distribution pattern of nutrients and phytoplankton.

The study of the chlorophyll a concentration using remote sensing (MODIS and Landsat) in the north waters of Java has been conducted by several researchers including Siregar \& Koropitan (2016); Shabrina et al. (2017); Subiyanto (2017); Wirasatriya et al. (2018). Likewise, the study of the chlorophyll a concentration by taking samples in the field has been carried out by Maslukah et al. (2019). The research on chlorophyll a due to the influence of global climate has been done, the analysis was carried out over a wide area, but has never been discussed in terms of the difference in the value of chlorophyll a in the areas with different levels of anthropogenic activity and it has never been studied how the concentration of chlorophyll a results from the image data and field data.

The purpose of this study was to investigate the variability pattern of chlorophyll a (chl-a) temporally, using field measurement data and remote sensing data (MODIS-Aqua). Geographically, the areas studied are different and are located in coastal waters with a narrow area, close to the mainland and have different levels of anthropogenic activity. The MODIS imagery data for four years was used to observe the time series fluctuations, while the field data was used to describe the condition of chlorophyll a near the coast, due to the inexistence of image data in the areas near the coast.

\section{MATERIAL AND METHOD}

The data used in this study is chlorophyll a, the results of field measurements using the spectrometry method and MODIS-aqua imagery. The water sampling for (chl-a) analysis was conducted in May 2017, May 2018, February \& July 2019 (Maslukah et al., 2020) and November 2019. The image data analyzed in this study was the result of four years of image recording (20152019 ), in $4 \times 4$ pixel. The location of the study is presented in Figure 1. The satellite image used in this study is MODIS-Aqua level III calibrated radians, obtained from NASA at the web address: http://rafidfire.sci.gsfc.nasa.gov/realtime.

The image analysis method involved extracting the sea level reflectance values using SeaDas software version 7.2.1, at the coordinate points closest to the coast. The locations of this study include the Semarang and Jepara coastal waters at the latitudes $-6.81^{\circ}$ to $-6.94^{\circ} \&$ longitudes $110.31-110.44^{\circ}$ and latitudes $-6.47^{\circ}$ to $-6.60^{\circ} \&$ longitudes $10.52-110.65^{\circ}$, respectively (Figure 1).

The analytical methods for measuring chlorophyll a in the field involved the (chl-a) analysis using the trichromatic method (APHA, 1992). A total of 1 liter of seawater was filtered with cellulose filter paper (millipore, $0.45 \mu \mathrm{m}$ ), extracted with $10 \mathrm{ml}$ of $90 \%$ acetone, and incubated in an refrigerator for 16 hours. The next step is centrifuged with $4000 \mathrm{rpm}$ rotation, and the supernatant reads its absorbance values at $\lambda 664, \lambda 645$ and $\chi 630$. Absorbance at $\chi 750$ was used as turbidity control. The chlorophyll a concentration was calculated using formula 1 and 2 :

$$
\begin{gathered}
\mathrm{Chl}-\mathrm{a}=11.85(\lambda 664)-1.54(\lambda 647)- \\
-0.008(\lambda 630)
\end{gathered}
$$

Concentration of chl-a $\left(\mathrm{mg} \mathrm{m}^{-3}\right)=$

$$
=\mathrm{Ca} \times v / V
$$

where: $\lambda 664-$ value of absorbance at wavelength $664 \mathrm{~nm}$, 


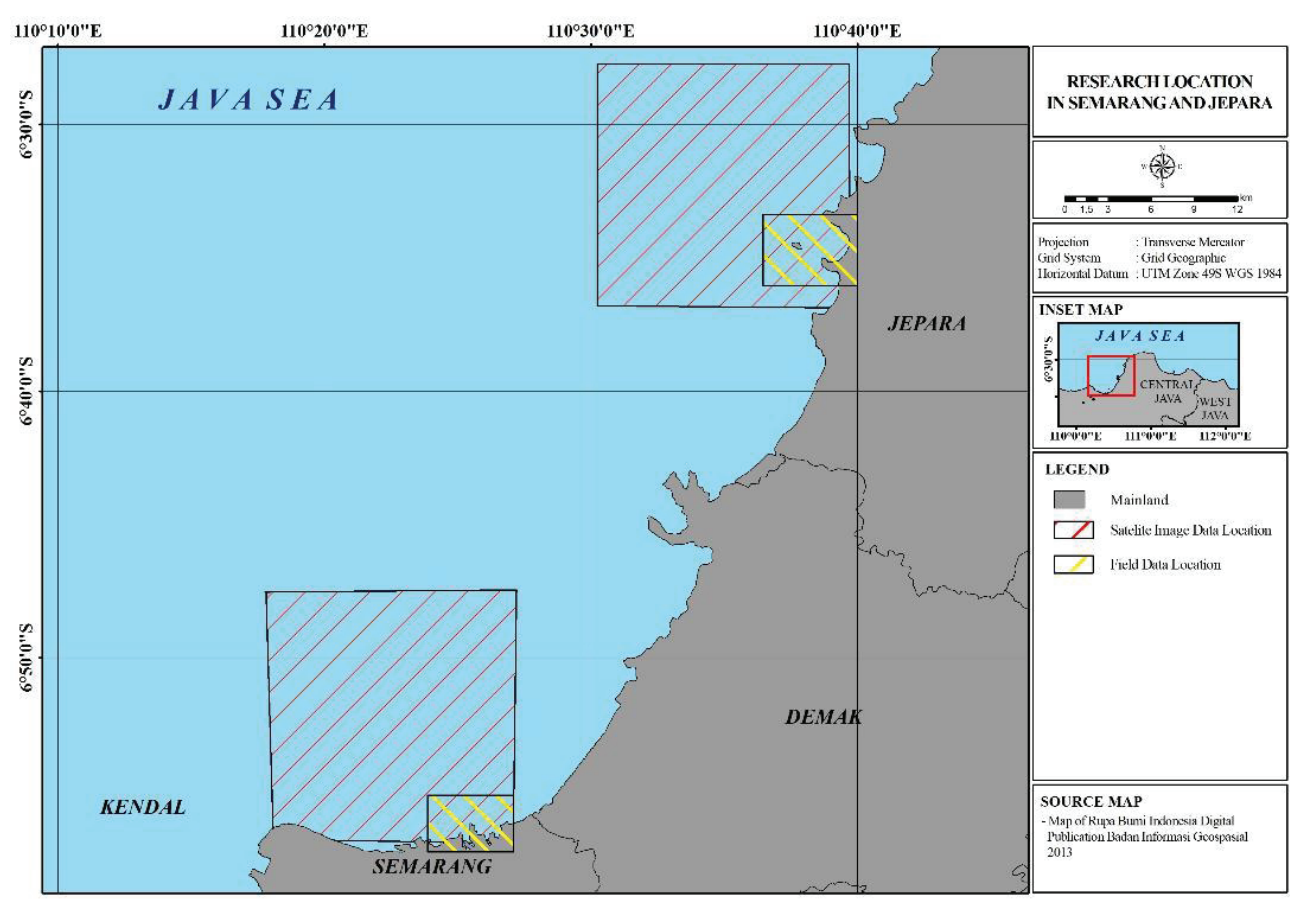

Figure 1. Research location

$\lambda 645$ - value of absorbance at wavelength $645 \mathrm{~nm}$,

$\lambda 630$ - value of absorbance at wavelength $630 \mathrm{~nm}$,

$V$ - volume of extract (liter),

$V$ - volume of sample (m).

\section{RESULT AND DISCUSSION}

\section{Chlorophyll a in Modis-Aqua Imagery}

On the basis of the MODIS-Aqua imagery data, the chlorophyll a value of northern waters in Central Java is in the range of 0.45$5.72 \mathrm{mg} \cdot \mathrm{m}^{-3}$ (Table 1 ). The results of the analysis for five years (2015-2019) indicate that the Semarang waters always show higher and more fluctuating values compared to the Jepara waters, with average ( \pm standard deviation) of $2.77 \pm$ $1.06 \mathrm{mg} \cdot \mathrm{m}^{-3}$ and $1.22 \pm 0.57 \mathrm{mg} \cdot \mathrm{m}^{-3}$, respectively. The ratio of the chlorophyll a value of the average five years of the Semarang waters to Jepara shows a ratio value of 2.2. The results of Siregar \& Koropitan (2016) using the Landsat data showed the chlorophyll a concentration in the Semarang waters between $0.6-2.1 \mathrm{mg} \mathrm{m}^{-3}$, while based on the results of MODIS-Aqua in the northern waters of Central Java showed a range of values between $0.5-1.0 \mathrm{mgv} \cdot \mathrm{m}^{-3}$ (Shabrina et al., 2018).
The climatological fluctuation pattern for five years can be seen in Figure 2 and the spatial distribution pattern is illustrated in Figures 3 and 4 . Figure 2 shows that the maximum chlorophyll a value in April $\left(3.85 \mathrm{mg} \cdot \mathrm{m}^{-3}\right)$ and vice versa, the Jepara waters occurred in February $\left(1.75 \mathrm{mg} \cdot \mathrm{m}^{-3}\right)$. The pattern of fluctuations in the Semarang region is generally almost the same as that of Shabrina et al. (2018) and this pattern is related to high temperatures in April-June and nutrients due to the rainy season runoff, which were produced in the previous month. The spatial pattern of climatology for four years was presented in Figures 3 and 4.

Figure 3 shows that the distribution of chlorophyll a in the Semarang coastal waters from south to north (except in 2018). This condition is different in the Jepara waters, which have a distribution pattern from east to west. This distribution pattern is morphologically related to the land location. Figure 3 and 4 show that high concentrations are sourced from the mainland and are getting smaller towards the open waters.

\section{The Field Measurements of the Chlorophyll a Concentration}

The value of chlorophyll a concentration in the field measurements, obtained using the spectrometry method, shows that the chlorophyll 
Table 1. The monthly average of chlorophyll a in 2015-2019

\begin{tabular}{|l|c|c|c|c|c|c|c|c|c|c|}
\hline \multirow{2}{*}{ Month } & \multicolumn{2}{|c|}{2019} & \multicolumn{2}{c|}{2018} & \multicolumn{2}{c|}{2017} & \multicolumn{2}{c|}{2016} & \multicolumn{2}{c|}{2015} \\
\cline { 2 - 15 }$y$ & SMRG & JPR & SMRG & JPR & SMRG & JPR & SMRG & JPR & SMRG & JPR \\
\hline January & 2.14 & 1.73 & 3.22 & $*$ & 3.01 & 2.67 & 1.43 & 0.61 & 1.80 & $*$ \\
\hline February & 5.72 & 0.75 & 4.13 & 2.18 & 1.08 & & 2.28 & 2.32 & 2.79 & $*$ \\
\hline March & 3.90 & 1.94 & 2.20 & 1.69 & 3.27 & 1.18 & 1.36 & 0.48 & 3.77 & 0.46 \\
\hline April & 2.91 & 0.58 & 4.09 & 0.47 & 3.10 & 0.58 & 3.48 & 0.45 & 5.67 & 1.94 \\
\hline May & 3.01 & 1.32 & 3.27 & 1.31 & 5.51 & 0.74 & 1.89 & 1.03 & 4.34 & 1.06 \\
\hline June & 2.89 & 1.98 & 2.11 & 1.56 & 2.83 & 1.29 & 3.75 & 1.42 & 4.92 & 1.95 \\
\hline July & 2.52 & 1.70 & 2.58 & 1.38 & 3.08 & 1.51 & 4.28 & 1.33 & 2.26 & 1.52 \\
\hline August & 1.74 & 1.82 & 1.98 & 1.64 & 2.02 & 1.70 & 2.14 & 1.32 & 2.43 & 2.04 \\
\hline September & 1.91 & 3.46 & 2.73 & 1.24 & 2.17 & 0.75 & 2.73 & 0.97 & 2.07 & 1.07 \\
\hline October & 1.59 & 0.86 & $*$ & 0.77 & 0.76 & 0.91 & 2.28 & $*$ & 1.59 & $*$ \\
\hline November & 1.71 & 0.93 & 2.47 & $*$ & $*$ & $*$ & 2.00 & 0.90 & 1.12 & 0.53 \\
\hline December & $*$ & $*$ & $*$ & 0.35 & 4.17 & 1.44 & 2.50 & & 1.87 & 0.60 \\
\hline Average & 2.73 & 1.55 & 2.88 & 1.26 & 2.82 & 1.28 & 2.51 & 1.08 & 2.88 & 1.24 \\
\hline STD & 1.16 & 0.77 & 0.74 & 0.55 & 1.27 & 0.58 & 0.87 & 0.53 & 1.39 & 0.61 \\
\hline
\end{tabular}

SMRG: Semarang; JPR: Jepara; STD: standard deviation.

a value of the Semarang waters shows a higher value than the Jepara waters (Figure 5). The results of field measurements from May 2017 to October 2019 show the values ranging from $11.41-18.81 \mathrm{mg} \cdot \mathrm{m}^{-3}$ (average $15.25 \pm 3.14$ ) for the Semarang waters and $3.95-12.34 \mathrm{mg} \cdot \mathrm{m}^{-3}$ (average $7.13 \pm 4.54$ ) for the Jepara waters. Maslukah et al. (2020a) explained that the high chlorophyll a is related to the high concentration of dissolved phosphate (DIP) in the Semarang coastal waters. In addition to the $\mathrm{P}$ nutrient input from river flows, the Semarang's coastal sediment contributes three times higher DIP than the Jepara sediment (Maslukah et al., 2020b). On the basis of the mean value during the measurement of the field data, the ratio of chlorophyll a concentration of the Semarang coastal waters to Jepara shows a value ratio of 2.1 .
The results of chlorophyll a chl-a measurements using the image and field data indicate that the field data show values greater than the data from images (Figure 6) and the value of the comparison ratio in 2019 was presented in Figure 7. The results of previous studies (Brando et al., 2006; Zheng \& DiGiacomo, 2017; Yoon et al., 2019) explained that the chlorophyll a concentration on the coast was underestimated due to the influence of CDOM reflectance and bathymetry. The estimation result of chl-a derived from Geostationary Ocean Colour Imager (GOCI) using several (chl-a) algorithms shows a relatively lower mean value for the (chl-a) estimation (mean range: $0.7-1.0 \mathrm{mg} \cdot \mathrm{m}^{-3}$ ) compared to the value chl-a in situ (Yoon et al., 2019).

High chlorophyll a (chl-a) values from field measurements were related to sampling closer to

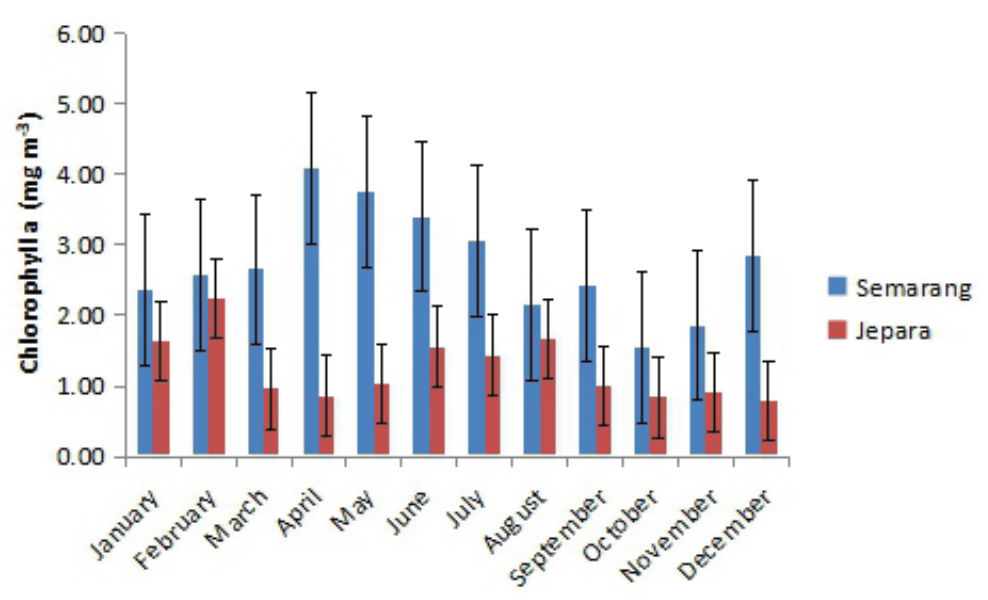

Figure 2. Chlorophyll a climatology fluctuations in the waters of Semarang and Jepara (2015-2019) 
the land no more than $3 \mathrm{~km}$ to the sea and in a narrower area, unlike the image data, obtained from a wider area towards the high seas (approximately $16 \mathrm{~km}$ from the coast). However, based on the chlorophyll a values of the two study areas, the measurement data through two methods (field measurements and image data), showed almost the same ratio values. The ratio of the Semarang waters to the Jepara waters uses image data in the amount of 2.2 and based on field data of 2.1. The coastal waters of Semarang itself have a ratio of field data to MODIS-Aqua imagery of 5.5 and Jepara is 5.5 (Table 2). Poddar et al. (2019), also shows that in situ (field) data show a higher value than MODIS and Landsat imagery.

On the basis of Table 2 it can be seen that the ratio obtained between the field data and the image approaches the same value. Therefore, the use of remote sensing applications can be used in monitoring the chlorophyll a concentrations in waters and can facilitate assessing large areas in a short time. Prianto et al. (2013) explained that the dynamics of the waters always change, so the resulting image data will not always be the same as the value of chlorophyll a concentration measurements in the field.

On the basis of the results of imagery and field data, the value of chlorophyll a in the Semarang waters always shows a high value. This illustrates that the waters of Semarang are more fertile than Jepara, due to the influence of high anthropogenic activity. High anthropogenic activity contributes to the input of organic matter and nutrients into these waters. The results of the study of Maslukah et al. (2019) stated that the measured concentration of the P nutrient in the Semarang waters was higher $(0.5 \mu \mathrm{M})$ than in the Jepara waters $( \pm 0.35 \mu \mathrm{M})$.

\section{Trophic status classification by several researchers}

Chlorophyll a can be used as a parameter of water quality. Many indices have been proposed for the classification of coastal waters into oligotrophic. mesotrophic and eutrophic water types. If the coastal waters have low productivity, they are characterized as "oligotrophic", whereas the waters are rich in algal biomass are characterized

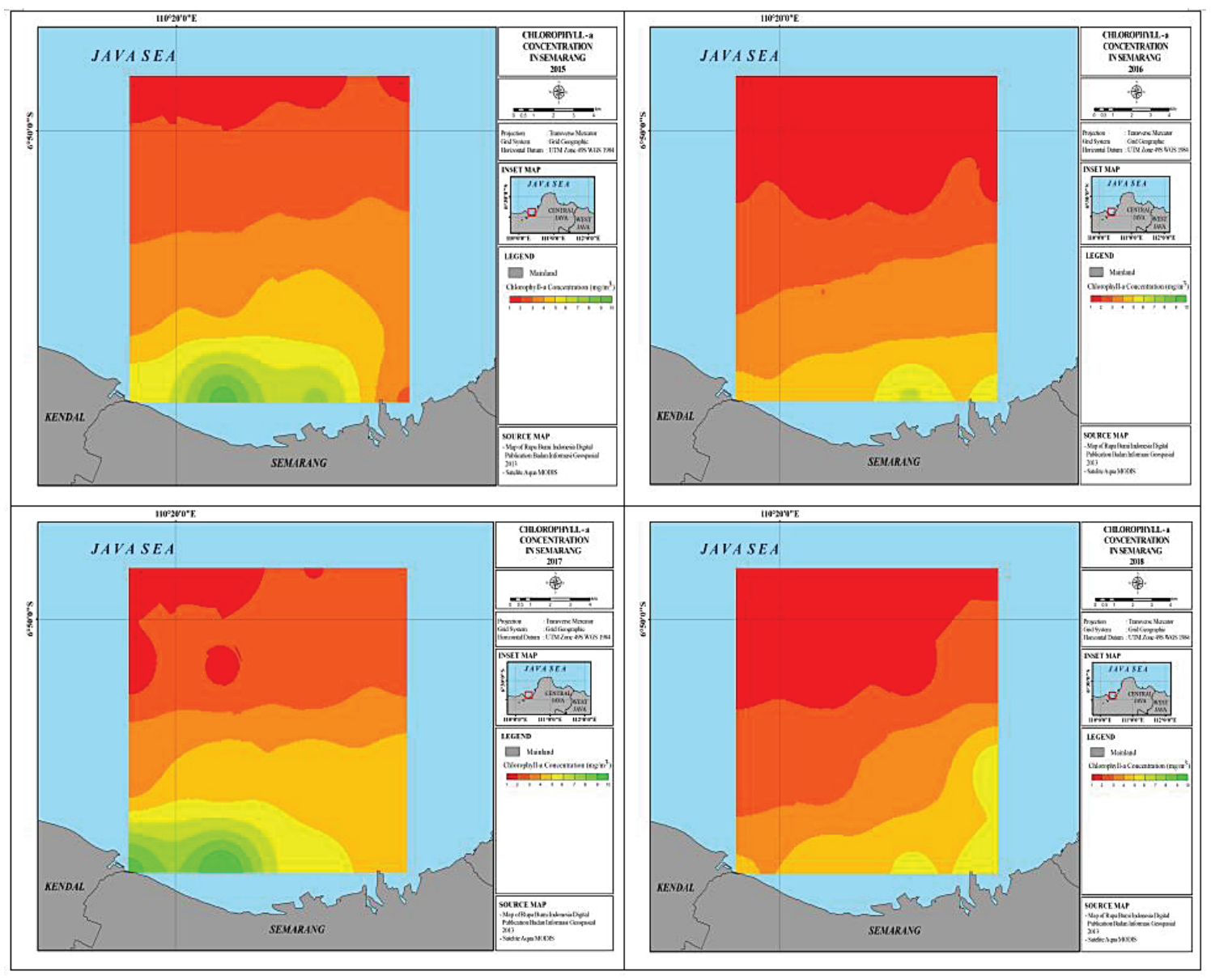

Figure 3. Distribution patterns of chlorophyll a, annual climatology values in the Semarang coastal waters 


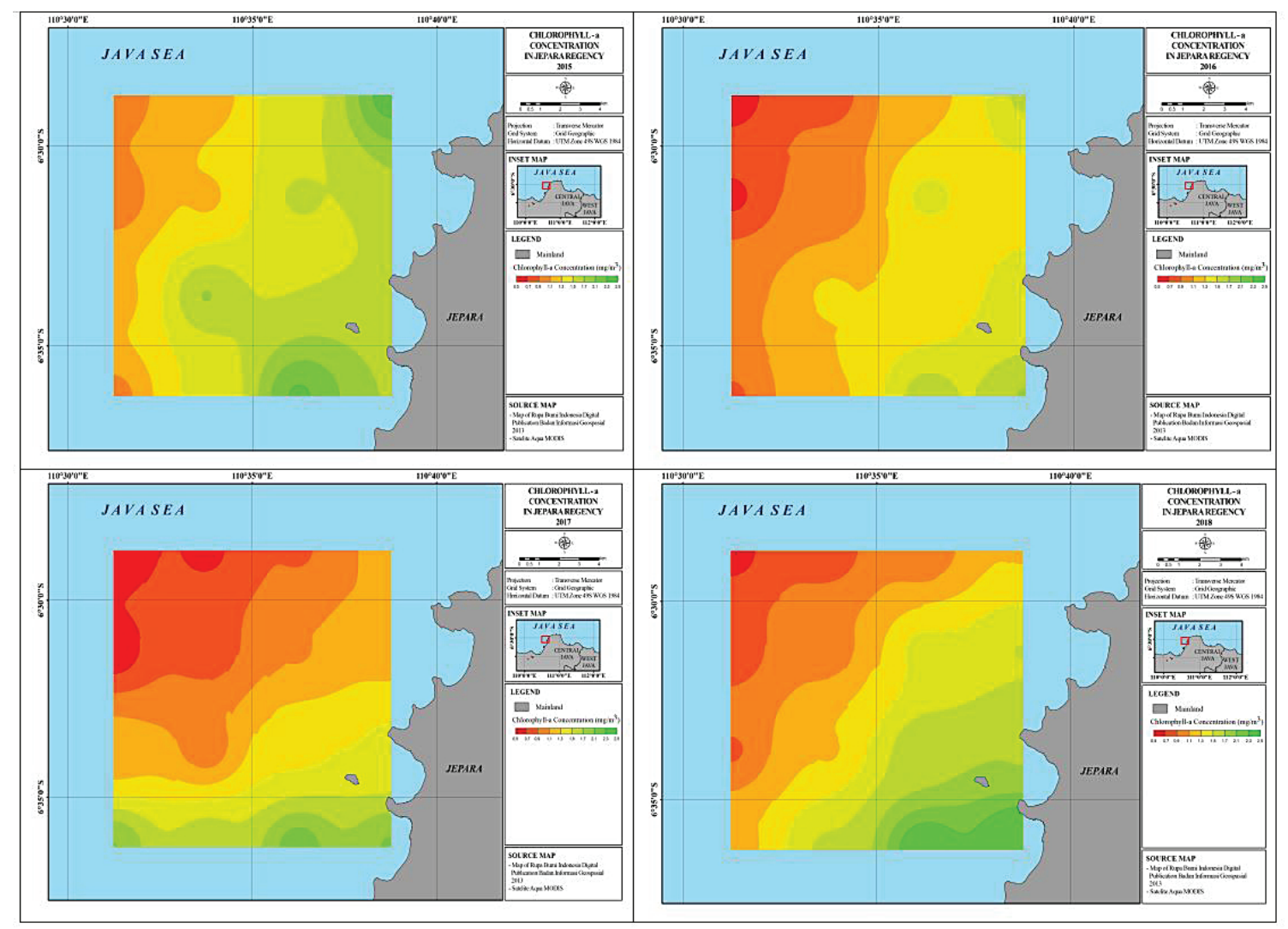

Figure 4. Distribution patterns of chlorophyll a, annual climatology values in the Jepara coastal waters

Table 2. The average of chlorophyll a $\left(\mathrm{mg} \cdot \mathrm{m}^{-3}\right)$ and ratio between MODIS-Aqua and field data in the coastal waters of Semarang and Jepara

\begin{tabular}{|l|c|c|c|}
\hline \multicolumn{1}{|c|}{ Description } & Semarang & Jepara & Ratio \\
\hline MODIS Data & 2.8 & 1.3 & 2.2 \\
\hline Field Data & 15.2 & 7.1 & 2.1 \\
\hline Ratio & 5.5 & 5.6 & - \\
\hline
\end{tabular}

as "eutrophic" and the intermediate condition is characterized as "mesotropy". Hakanson and Bryann (2008) explained that oligotrophy occurs in the waters with chlorophyll-a concentration $<2 \mu \mathrm{g} \cdot \mathrm{L}^{-1}\left(\mu \mathrm{g} \cdot \mathrm{L}^{-1}=\mathrm{mg} \cdot \mathrm{m}^{-3}\right)$, mesotrophic waters (2-6 $\left.\mu \mathrm{g} \cdot \mathrm{L}^{-1}\right)$, eutrophic waters $\left(6-20 \mu \mathrm{g} \cdot \mathrm{L}^{-1}\right.$, hypereutrophic waters $\left(\mathrm{chl}-\mathrm{a}>20 \mu \mathrm{g} \cdot \mathrm{L}^{-1}\right)$.

On the basis of the classification, the value of chlorophyll a obtained from field observations in the north coast of Java shows that the Semarang coastal waters are classified as eutrophic and the Jepara waters in the mesotrophic category. The results of the classification will be different if monitoring is performed using the image data. The Semarang waters are in the mesotrophic category $\left(>2 \mathrm{mg} \cdot \mathrm{m}^{-3}\right)$ and Jepara is oligotrophic waters $\left(<2 \mathrm{mg} \cdot \mathrm{m}^{-3}\right)$.
On the basis of the MODIS-Aqua satellite (Table 1), the Semarang and Jepara waters have values $<10 \mathrm{mg} \mathrm{m}^{-3}$. In the case of eutrophication that had occurred in the Jakarta Bay, in 2010, the value of chlorophyll a reached $10 \mathrm{mg} \cdot \mathrm{m}^{-3}$ in the waters near the coast and further showed a decrease reaching $0.25 \mathrm{mg} \cdot \mathrm{m}^{-3}$ (Tarigan et al., 2013). In turn, based on the results of field research in the Jakarta Bay area, the value of chlorophyll a ranges from $1.83-11.45 \mu \mathrm{g} \cdot \mathrm{L}^{-1}$ (Palimirmo et al., 2016), in the Sunter estuary (Central Jakarta Bay) around 0.78-15.74 $\mu \mathrm{g} \cdot \mathrm{L}^{-}$ ${ }^{1}$ and ranges from $0.27-19.98 \mu \mathrm{g} \cdot \mathrm{L}^{-1}$ (Prayitno \& Afdal, 2019). Li et al. (2002) and Wouthuyen et al. (2006) explained that if the concentration of chlorophyll a $>10 \mathrm{mg} \cdot \mathrm{m}^{-3}\left(\mathrm{mg} \cdot \mathrm{m}^{-3}=\mu \mathrm{g} \cdot \mathrm{L}^{-}\right.$ $\left.{ }^{1}\right)$, then there is abundance of phytoplankton in the waters. Ignatiades (2005) classifies waters included in the oligotropic category for open waters (Aegean Sea), if the chlorophyll a values range from 0.16 to $0.37 \mathrm{mg} \cdot \mathrm{m}^{-3}$, mesotrophic ranges from 0.45 to $0.61 \mathrm{mg} \cdot \mathrm{m}^{-3}$ (offshore Saronikos Gulf water) and eutrophic from 1.16$1.84 \mathrm{mg} \cdot \mathrm{m}^{-3}$ (inshore Saronikos Gulf Water). In a review of marine systems, Smith et al. (1999) defined the mesotrophic status as the chlorophyll 


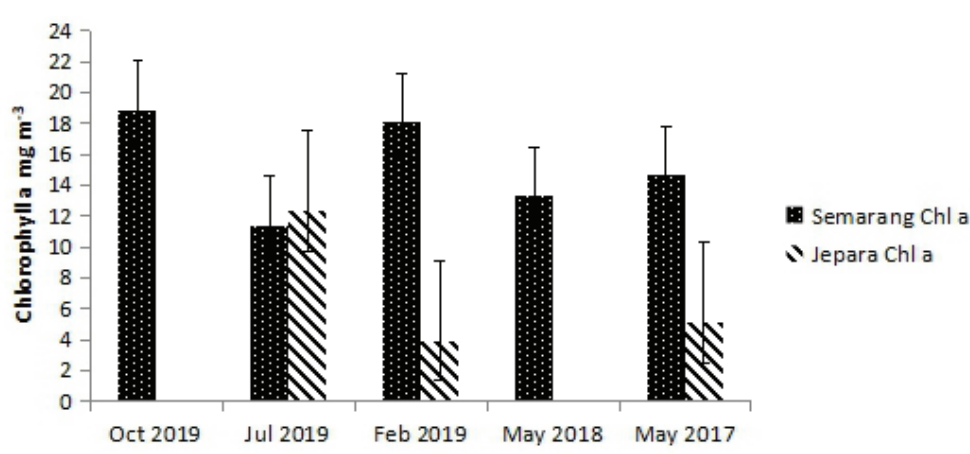

Figure 5. Chlorophyll a concentration based on the results of field measurements (spectrometry method)

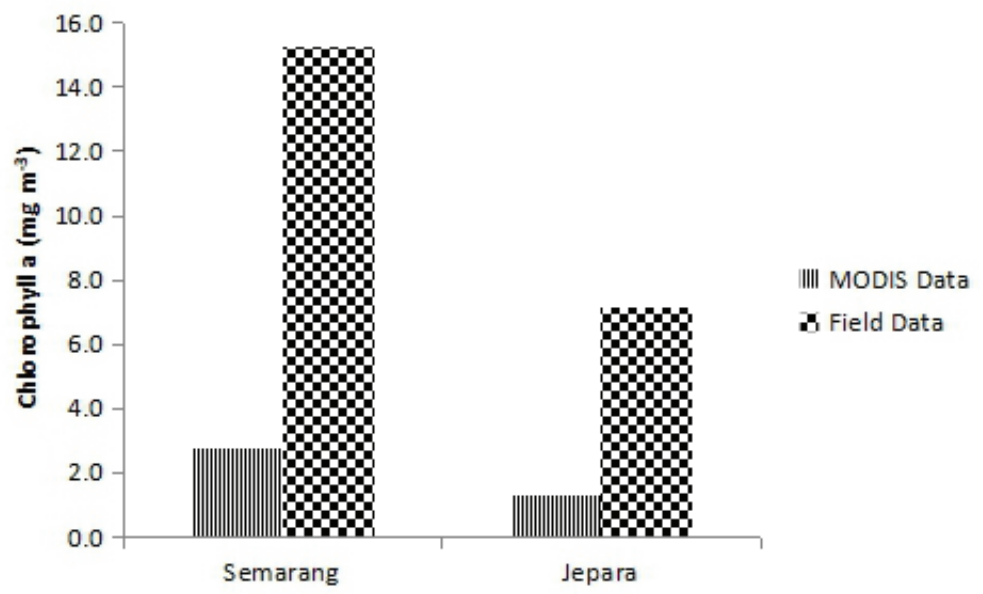

Figure 6. The average chlorophyll a in AQUA MODIS (2015-2019) and the field observation (2017-2019)

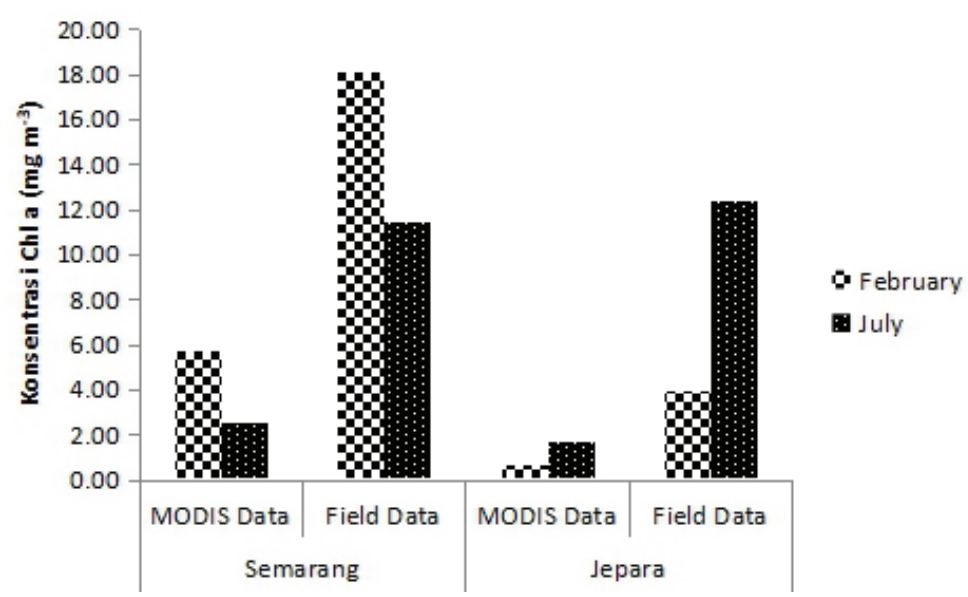

Figure 7. The average chlorophyll a in AQUA MODIS and the field observation in 2019

a concentrations ranging from 1 to $3 \mu \mathrm{g} \mathrm{L}^{-1}$ and hypereutrophic at concentrations $\left.>5 \mu \mathrm{g} \cdot \mathrm{L}^{-1}\right)$.

\section{CONCLUSION}

The results showed that the chlorophyll a concentration from the field measurements in coastal waters showed a value five times higher than the image data. The image data and the field measurement data of primary productivity values (chlorophyll a) both show the ratio is close to twice the value. The Semarang waters with high anthropogenic activity levels have higher chlorophyll a than the Jepara waters. The results of the MODIS-Aqua satellite and field measurements for the waters of Semarang and Jepara are 2.8 and $15.2 \mathrm{mg} \cdot \mathrm{m}^{-3}$ and 1.3 and $7.1 \mathrm{mg} \cdot \mathrm{m}^{-3}$, 
respectively. The MODIS-Aqua data in coastal waters is often not available due to not being recorded. Thus, it is still necessary to monitor the continuous field data and image data can be considered for monitoring on a wider scale and in a long time. It is necessary to develop monitoring of chlorophyll a in coastal areas using more appropriate satellite data.

\section{Acknowledgments}

This study is funded by Selain APBN Universitas Diponegoro Tahun 2020, under scheme Program Penelitian Kolaborasi Indonesia (PPKI), Contract no. 193.05/UN7.6.1/PP/2020. Aqua MODIS level III calibrated radians, obtained from NASA at the web address: http://rafidfire. sci.gsfc.nasa.gov/realtime.

\section{REFERENCES}

1. APHA. 1992. Standard method for the examination of water and wastewater. 18th edition. Washington, pp. 252.

2. BPDAS Pemali Jratun. 2009. Watershed management information system Central Java.

3. Brando, V. Dekker, A., Marks, A., Qin, Y. \& Oubelkheir, K. 2006. Chlorophyll and suspended sediment assessment in a macrotidal tropical estuary adjacent to the Great Barrier Reef: spatial and temporal assessment using remote sensing. Cooperative Research Centre for Coastal Zone, Estuary and Waterway Management (Coastal CRC). Indooroopilly, Australia. pp. 111.

4. Brewin, R.J.W., Morán, X. A. G., Raitsos, D.E., Gittings, J.A., Calleja, M.L., Viegas, M., Ansari, M.I., Al-Otaibi, N., Huete-Stauffer, T.M., \& Hoteit, I. 2019. Factors regulating the relationship between total and size-fractionated chlorophyll a in coastal waters of the Red Sea. Front. Microbiol. 10:1964. doi: 10.3389/fmicb.2019.01964.

5. Colella, S., Falcini, F., Rinaldi, E., Sammartino, M., \& Santoleri, R. (2016). Mediterranean ocean colour chlorophyll trends. PLoS ONE, 11(6). https: //doi. org /10.1371/ journal.pone.0155756.

6. Dickey, T., Lewis, M., Chang, G., 2006. Optical oceanography: recent advances and future directions using global remote sensing and in situ observations. Rev. Geophys. 44.RG1001.

7. Hakanson, L and A.C. Bryann. 2008. Eutrophication in the Baltic Sea present situation, nutrien transport processes, remedial strategies. Springer-Verlag Berlin Heidelberg, pp. 261.
8. Ignatiades, L. 2005. Scaling the trophic status of the Aegean Sea, eastern Mediterranean. Journal of Sea Research 54(1): 51-57. DOI: 10.1016/j. seares.2005.02.010.

9. Joint, I.; Groom, S.B. Estimation of phytoplankton production from space: Current status and future potential of satellite remote sensing. J. Exp. Mar. Biol. Ecol. 2000, 250, 233-255. [CrossRef].

10. Karydis, M. 2009. Eutrophication assessment of coastal waters based on indicators: a literature review. Global NEST Journal, 11 (4): 373-390. https://dx.doi.org/10.30955/gnj.000626.

11. Li, H. P., G.C. Gong dan T.M. Hsiung. 2002. Phytoplankton pigment analysis by HPLC and its application in algal community investigations. Bot. Bull. Acad. Sin 43: 283- 290.

12. Maslukah, L., Zainuri, M., Wirasatriya, A \& Salma, U. 2019. Spatial distribution of chlorophyll-a and its relationship with dissolved inorganic phosphate influenced by rivers in the North Coast of Java. Journal of Ecological Engineering. 20 (7): 18-25

13. Maslukah, L., Zainuri, M., Wirasatriya, A \& Maisyarah, S. 2020a. The Relationship among dissolved inorganic phosphate, particulate inorganic phosphate, and chlorophyll-a in different seasons in the coastal seas of Semarang and Jepara, Journal of Ecological Engineering, 21(3): 135-142.

14. Maslukah, L., Zainuri, M., Wirasatriya, A \& Widiaratih, R. 2020b. Kinetic study on adsorption and desorption ion phosphat (PO42-) in sediment Semarang dan Jepara. J. Ilmu dan Teknologi Kelautan Tropis, 12(2): 385-396. http://doi.org/10.29244/ jitkt.v12i2.32392.

15. Palimirmo, F.S., Damar, A \& Effendi, H. 2016. Distribution dynamic of heterotrophic bacteria in Jakarta Bay. JIPI, 21(1): 26-34. https://dx.doi. org/10.18343/jipi.21.1.26.

16. Poddar, S., Chacko, N. \& Swain, D. 2019. Estimation of chlorophyll-a in northern coastal bay of Bengal using landsat-8 OLI and sentinel-2 MSI sensors. Front. Mar. Sci, 6(598): 1-11. doi: 10.3389/ fmars.2019.00598.

17. Prayitno, H \& Afdal. 2019. Spatial distributions of nutrients and chlorophyll-a: a possible occurrence of phosphorus as a eutrophication determinant of the Jakarta bay. Jurnal Ilmu dan Teknologi Kelautan Tropis, 11(1): 1-12. http://dx.doi.org/10.29244/ jitkt.v11i1.21971.

18. Shabrina, B., Maslukah, L. \& Wulandari, S.Y. 2018. Chlorophyll-a distribution and its relation with current pattern in Northern Waters of Central Java. Omni-Akuatika, 14 (1): 69-76.

19. Siregar, V. and Koropitan, A.F. 2013. Primary productivity of Jakarta Bay in a changing environment: anthropogenic and climate change impacts. BIOTROPIA, 20(2): 89-103. https://dx.doi. 
org/10.11598/btb.2013.20.2.5.

20. Smith, V. H. 1999. Cultural eutrophication of inland, estuarine and coastal waters. In: Pace, M. L. and P. M. Groffman (eds.). Successes, Limitation and Frontiers in Ecosystem Science. Springer-Verlag, New York, New York, pp. 7-49.

21. Subiyanto, S. 2017. Remote sensing and water quality indicators in the west flood canal sema $\neg$ rang city: spatio-temporal structures of lansat-8 derived chlorophyll-a and total suspended sol-ids. IOP Conf. Series: Earth and Environmental Science 98, 1-10.

22. Tarigan, M.S \& Wiadnyana, N.N. 2013. Monitoring of chlorophyll-a concentration using terra-aqua modis satelitte image in Jakarta Bay. Jurnal Nasional Kelautan. 8(2), 81-89.

23. Wirasatriya A, Prasetyawan I.B., Triyono, C.D., Muslim and Maslukah, L. 2018. Effect of ENSO on the variability of SST and Chlorophyll a in Java Sea. IOP Conference Series: Earth and Environmental Science, 116 (012063).

24. Wouthuyzen, S., M.S. Tarigan, E. Kusmanto, H. Indarto dan Sugarin. 2006. Pemantauan Kualitas Perairan Teluk Jakarta untuk Memprediksi Mark Algae dengan Satelit Terra dan Aqua MODIS. Laporan Penelitian Kompetitif Jabopunjur-LIPI.

25. Yoon, J.-E., Lim, J.-H., Son, S., Youn, S.-H., Oh, H.J., Hwang, J.-D., Kwon, J.-I., Kim, S.-S. and Kim, I.-N,. 2019. Assessment of satellite-based chlorophyll a algorithms in eutrophic Korean coastal waters: Jinhae Bay Case Study. Front. Mar. Sci. 6:359. doi: 10.3389/fmars.2019.00359.

26. Zheng, G.\& DiGiacomo, P.M. 2017. Remote sensing of chlorophyll a in coastal waters based on the light absorption coefficient of phytoplankton. 201, 331-341. 